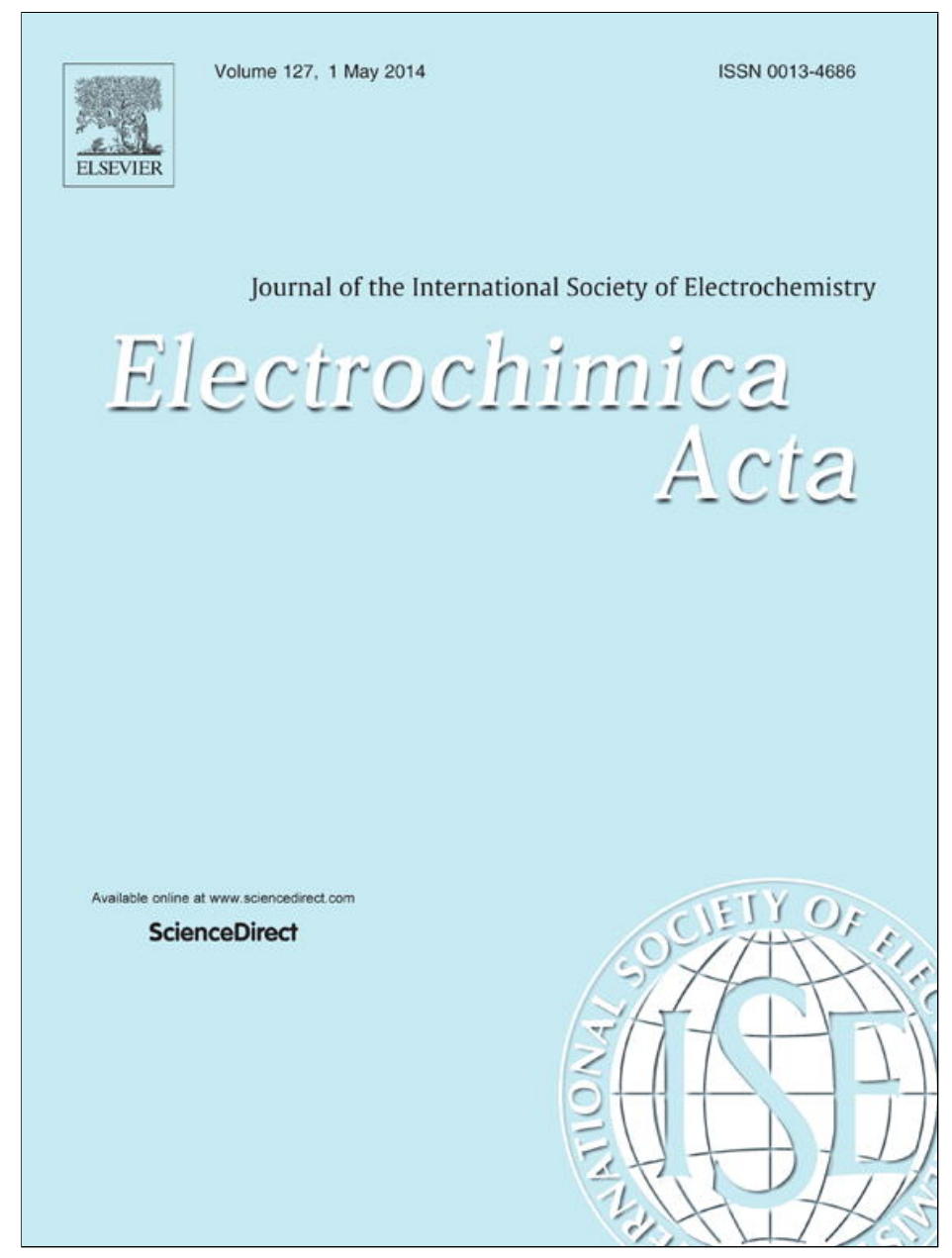

This article appeared in a journal published by Elsevier. The attached copy is furnished to the author for internal non-commercial research and education use, including for instruction at the authors institution and sharing with colleagues.

Other uses, including reproduction and distribution, or selling or licensing copies, or posting to personal, institutional or third party websites are prohibited.

In most cases authors are permitted to post their version of the article (e.g. in Word or Tex form) to their personal website or institutional repository. Authors requiring further information regarding Elsevier's archiving and manuscript policies are encouraged to visit:

http://www.elsevier.com/authorsrights 


\title{
Mechanisms of Film Growth on Copper in Aqueous Solutions Containing Sulphide and Chloride under Voltammetric Conditions
}

\author{
Taylor Martino, Raheleh Partovi-Nia, Jian Chen, Ziqiang Qin, David W. Shoesmith* \\ Department of Chemistry and Surface Science Western, The University of Western Ontario, London, Ontario, N6A 5B7, Canada
}

\section{A R T I C L E I N F O}

\section{Article history:}

Received 17 December 2013

Received in revised form 27 January 2014

Accepted 13 February 2014

Available online 24 February 2014

\section{Keywords:}

Copper

Sulphide

Corrosion

Rotating disk electrode

Cyclic voltammetry

\begin{abstract}
A B S T R A C T
The electrochemical behavior and film formation mechanisms of oxygen-free copper have been studied in aqueous solutions containing a wide range of sulphide and chloride concentrations using rotating disk electrodes and cyclic voltammetry. Scanning electron microscopy, energy dispersive X-ray spectroscopy and focused ion beam techniques were employed to characterize the morphology, composition and structure of the copper sulphide films formed on the copper surface under voltammetric conditions. These studies show that three distinct type of films were formed depending on the sulphide concentration, the flux of sulphide to the electrode surface, and the chloride concentration of the solution. The properties of the film and the mechanism of growth were determined by competition between sulphide diffusion in solution and the rate of interfacial reactions on the Cu surface. Comparison of these properties of electrochemically grown films to those of films grown under corrosion conditions indicates that pitting should not occur under the conditions expected in a nuclear waste repository.
\end{abstract}

(c) 2014 Elsevier Ltd. All rights reserved.

\section{Introduction}

A key requirement for the continued use of nuclear power is the successful management of the spent nuclear fuel. One approach under study in many countries, including Sweden, Finland and Canada, is permanent disposal of the spent fuel in a deep geological repository (DGR). In such disposal facilities the spent fuel would be placed in canisters, specifically designed to avoid both corrosion and mechanical failure. The container will be fabricated with a carbon steel insert, and an outer shell of copper. It is proposed that these containers be buried in crystalline rock approximately $500 \mathrm{~m}$ below the surface and the excavated boreholes backfilled with bentonite clay [1]. $\mathrm{Cu}$ is chosen since it should be inert to corrosion in the anoxic environments anticipated in a DGR [1-7]. The Cu layer would be about $50 \mathrm{~mm}$ thick and the metal would be $\mathrm{O}$-free and $\mathrm{P}$ doped. Removing the $\mathrm{O}$ and doping with small concentrations of $\mathrm{P}$ (30 to $100 \mathrm{ppm}$ ) improves the creep resistance, thereby limiting the possibility of physical deformation of the container after emplacement [8].

Although $\mathrm{Cu}$ is chosen for its thermodynamic resistance to corrosion in anoxic environments, Swedish repositories are known to contain $\mathrm{SH}^{-}$, produced in the groundwater as a consequence of

\footnotetext{
* Corresponding author. Tel.: +1 519661 2111x86366; fax: +1 5196613022 . E-mail address: dwshoesm@uwo.ca (D.W. Shoesmith).
}

$\mathrm{SO}_{4}{ }^{2-}$-reducing bacteria and mineral dissolution [9]. This is potentially detrimental to the container since $\mathrm{SH}^{-}$can act as an oxidant for $\mathrm{Cu}$. Container corrosion in the groundwaters anticipated in a repository would also be complicated by the presence of high concentrations of $\mathrm{Cl}^{-}$.

Previous studies have proposed that $\mathrm{Cu}$ corrosion begins with the adsorption of an anion [10] and corrosion in aqueous $\mathrm{SH}^{-}$solutions involves a similar first step [9],

$\mathrm{Cu}+\mathrm{SH}^{-} \rightarrow \mathrm{Cu}(\mathrm{SH})_{\mathrm{ads}}+\mathrm{e}^{-}$

followed by a slow reaction step involving $\mathrm{Cu}$ to produce a $\mathrm{Cu}_{2} \mathrm{~S}$ film, the overall process being supported by $\mathrm{H}^{+}$or $\mathrm{H}_{2} \mathrm{O}$ reduction [9],

$\mathrm{Cu}+\mathrm{Cu}(\mathrm{SH})_{\mathrm{ads}}+\mathrm{SH}^{-} \rightarrow \mathrm{Cu}_{2} \mathrm{~S}+\mathrm{H}_{2} \mathrm{~S}+\mathrm{e}^{-}$

In long-term experiments under these conditions a $\mathrm{Cu}_{2} \mathrm{~S}$ film (chalcocite) was formed. Since $\mathrm{Cu}_{2} \mathrm{~S}$ formed at a constant rate, the film can be considered only partially protective, and corrosion may also be facilitated by the complexation and solubilization of $\mathrm{Cu}^{\mathrm{I}}$ by $\mathrm{Cl}^{-}[11]$,

$\mathrm{Cu}(\mathrm{SH})_{\mathrm{ads}}+2 \mathrm{Cl}^{-} \rightarrow \mathrm{CuCl}_{2}^{-}+\mathrm{SH}^{-}$

Since the solubility product of $\mathrm{Cu}^{\mathrm{I}}$ in $\mathrm{SH}^{-}$solution is very small [9], any dissolved $\mathrm{Cu}^{\mathrm{I}}$ would be expected to eventually precipitate as $\mathrm{Cu}_{2} \mathrm{~S}$,

$2 \mathrm{CuCl}_{2}^{-}+\mathrm{SH}^{-} \rightarrow \mathrm{Cu}_{2} \mathrm{~S}+4 \mathrm{Cl}^{-}+\mathrm{H}^{+}$ 
Kinetic studies revealed two types of growth process dependent on $\left[\mathrm{SH}^{-}\right]$. At $\left[\mathrm{SH}^{-}\right]=5.0 \times 10^{-4} \mathrm{M}$ growth follows a parabolic law and is governed by the transport of the $\mathrm{Cu}^{+}$ion through the $\mathrm{Cu}_{2} \mathrm{~S}$ matrix or along grain boundaries in the $\mathrm{Cu}_{2} \mathrm{~S}$ film $[9,12]$. However, when the $\left[\mathrm{SH}^{-}\right]$is lower $\left(5.0 \times 10^{-5} \mathrm{M}\right)$, film growth is controlled by $\mathrm{SH}^{-}$diffusion, and the kinetics follow a linear growth law leading to a porous non-protective film [12].

A remaining question is whether or not, given that the $\left[\mathrm{Cl}^{-}\right]$ is expected to be high, pitting can occur in saline groundwaters containing $\mathrm{SH}^{-}$. For this to occur the surface film must be generally passivating with local breakdown sites, and the cathodic reaction, in this case $\mathrm{SH}^{-}$or $\mathrm{H}_{2} \mathrm{O}$ reduction, must be sustained on the passive surface outside the pitting area.

In this paper, a series of voltammetric experiments (alternatively called polarization experiments) were performed in solutions containing a range of $\left[\mathrm{SH}^{-}\right]$and $\left[\mathrm{Cl}^{-}\right]$. These studies serve two functions: (i) they provide information on the sulphide film growth process on $\mathrm{Cu}$; and (ii) they enable us to determine when passivation occurs and whether or not this can lead to film breakdown and the initiation of pitting.

\section{Experimental}

\subsection{Electrochemical cell and instrumentation}

All electrochemical data were collected using a conventional three-electrode electrochemical glass cell. A Pt sheet rolled into a cylinder was used as the counter electrode and connected to external circuitry by a Pt wire. A standard calomel electrode (SCE, $0.242 \mathrm{~V}$ vs. SHE) was used as the reference electrode for all experiments. The cell was housed inside a Faraday cage to reduce electrical noise from external sources. All experiments were conducted using a rotating disc working electrode. The electrode rotation rate was controlled by a Pine Instrument Company Analytical Rotator Model AFA86 Serial 882, and electrochemical measurements were made using a 1287 Solartron potentiostat connected to a computer equipped with CorrWare software.

\subsection{Cu composition and preparation}

O-free, P-doped $\mathrm{Cu}$ provided by the Swedish Nuclear Fuel \& Waste Management Co. (SKB), Stockholm, Sweden, was machined into $\mathrm{Cu}$ disks. Ti rods were threaded into the back of the discs and the $\mathrm{Cu}$ was set into a Teflon holder using an epoxy resin. Only a single flat $\mathrm{Cu}$ face with a surface area of $0.785 \mathrm{~cm}^{2}$ was exposed to solution. Prior to an experiment, the $\mathrm{Cu}$ electrode was first ground with a sequence of $\mathrm{SiC}$ papers with grit sizes: 1000,1200 , and 4000 . Then, to achieve a mirror finish, the electrode was polished with $\mathrm{Al}_{2} \mathrm{O}_{3}$ suspensions with decreasing suspension size $(1 \mu \mathrm{m}, 0.3 \mu \mathrm{m}$, and $0.05 \mu \mathrm{m})$. The electrode was then rinsed thoroughly with Type I water (resistance: $18.2 \mathrm{M} \Omega \cdot \mathrm{cm}$ ) to remove any polishing residue and dried in a stream of ultrapure Ar gas.

\subsection{Solutions}

Electrolyte solutions were prepared with Type I water obtained using a NANOPure system. Chemicals were reagent-grade and purchased from Caledon Laboratories Ltd. All water was purged with Ar gas for one hour prior to the preparation of solutions. The actual $\left[\mathrm{SH}^{-}\right]$used were higher than those anticipated in a repository. The $\left[\mathrm{Cl}^{-}\right]$were representative of the range of groundwater concentrations anticipated. The $\mathrm{NaCl}$ and $\mathrm{Na}_{2} \mathrm{~S} \cdot 9 \mathrm{H}_{2} \mathrm{O}$ concentrations used are listed in Table 1 . Since $\mathrm{Na}_{2} \mathrm{~S}$ was stored in the hydrated form, the crystals were dried before being weighed to minimize error in calculated concentrations. Once in the electrochemical cell, the
Table 1

$\mathrm{NaCl}$ and $\mathrm{Na}_{2} \mathrm{~S}$ concentrations.

\begin{tabular}{ll}
\hline $\mathrm{NaCl}$ concentration/M & $\mathrm{Na}_{2} \mathrm{~S}$ concentration/M \\
\hline 0.1 & $5.0 \times 10^{-5}$ \\
0.5 & $1.0 \times 10^{-5}$ \\
1.0 & $5.0 \times 10^{-4}$ \\
3.0 & $1.0 \times 10^{-3}$ \\
5.0 & $2.0 \times 10^{-3}$ \\
\hline
\end{tabular}

solution was purged for a minimum of 45 minutes before an experiment to ensure an anoxic environment. Subsequently, the solution was continuously purged with a stream of Ar gas.

\subsection{Cyclic voltammetry (CV)}

Cyclic voltammetry (CV) was used to investigate the mechanism of sulphide film formation. Prior to applying a voltammetric scan, the electrode was cathodically cleaned at $-1.5 \mathrm{~V} / \mathrm{SCE}$ to remove air-formed oxides, and then at $-1.15 \mathrm{~V} / \mathrm{SCE}$ for a further $60 \mathrm{~s}$. Voltammetric scans were performed from an initial potential in the range $-1.15 \mathrm{~V} / \mathrm{SCE}$ to $-1.5 \mathrm{~V} / \mathrm{SCE}$ to various anodic limits at a scan rate of $2 \mathrm{mV} / \mathrm{s}$. The choice of starting potential had no influence on the subsequent electrochemical behavior.

\subsection{Scanning electron microscopy (SEM)}

Surface imaging was performed using a LEO (Zeiss) 1540XB FIB/SEM equipped with an Energy Dispersive X-ray Spectroscopy (EDX) analyzer to elucidate the elemental composition of the surface. Analyses were performed at the Western Nanofabrication Facility. Focused ion beam (FIB) cross-sections were prepared using a Ga ion beam. The sample was not pre-coated before a cut was made.

\section{Results and discussion}

$\mathrm{CVs}$ were performed in solutions with various $\left[\mathrm{Cl}^{-}\right]$and $\left[\mathrm{SH}^{-}\right]$ and at various electrode rotation rates from 0 to $157 \mathrm{rad} / \mathrm{s}$. The anodic and cathodic current responses varied with solution composition, electrode rotation rate, and the anodic potential limit of the voltammetric scan. The results can be grouped into three distinct types of behaviour defined by the characteristics of the copper sulphide film.

\subsection{Type I-Single layer porous $\mathrm{Cu}_{2} \mathrm{~S}$ film}

Type I films were observed at the two lowest $\left[\mathrm{SH}^{-}\right]\left(5.0 \times 10^{-5} \mathrm{M}\right.$ and $\left.1.0 \times 10^{-4} \mathrm{M}\right)$ irrespective of changes in $\left[\mathrm{Cl}^{-}\right]$and mass transport conditions. A similar Type-I film was produced at $0.1 \mathrm{M}$ chloride in the $\left[\mathrm{SH}^{-}\right]$range from $5.0 \times 10^{-5} \mathrm{M}$ to $2.0 \times 10^{-3} \mathrm{M}$, and also at $0.5 \mathrm{M}$ and $1.0 \mathrm{M}$ chloride providing the $\left[\mathrm{SH}^{-}\right]$was in the range $5.0 \times 10^{-5} \mathrm{M}$ to $5.0 \times 10^{-4} \mathrm{M}$, and providing the solution was stagnant or the rotation rate was low (i.e., $10.5 \mathrm{rad} / \mathrm{s}$ ).

At a stationary electrode, Fig. 1, the shape of the anodic current peak for $\mathrm{Cu}_{2} \mathrm{~S}$ formation suggests film formation was diffusion controlled. On the reverse cathodic scan, a single, almost symmetrical peak for the reduction of $\mathrm{Cu}_{2} \mathrm{~S}$ was observed at $-1.15 \mathrm{~V} / \mathrm{SCE}$. When the electrode was rotated, Fig. 2, the flux of $\mathrm{SH}^{-}$to the electrode surface was accelerated and the presence of an anodic current plateau, with the current dependent on electrode rotation rate, confirms that film growth was dominantly a diffusion-controlled process. On the reverse scan the anodic current retraced its original path, confirming that film growth was reversible and that the sulphide film did not passivate the $\mathrm{Cu}$ surface. The size of the single reduction peak increased with rotation rate, and integration of the anodic and 


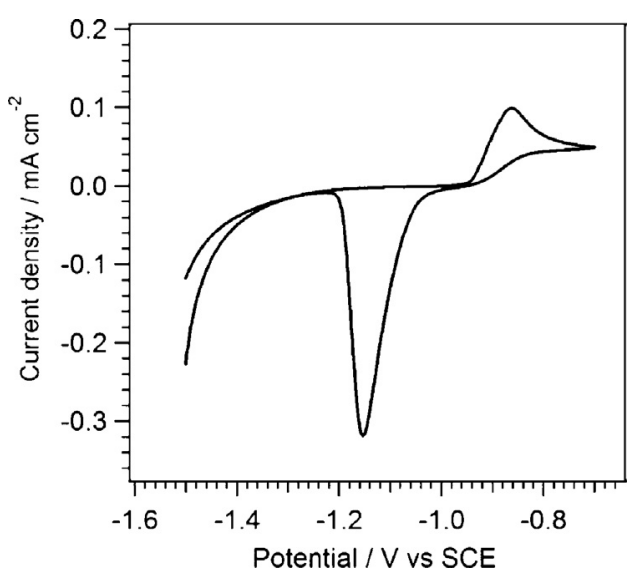

Fig. 1. CV recorded on a stationary electrode in $0.1 \mathrm{M}$ chloride $+1.0 \times 10^{-3} \mathrm{M}$ sulphide solution.

cathodic sections of the curve showed the total charge consumed in film growth was recovered in film reduction. The current at the negative potential limit on both the forward and reverse scans was due to $\mathrm{H}_{2} \mathrm{O}$ reduction.

To maintain a diffusion controlled growth process the film must be porous allowing rapid transport of $\mathrm{Cu}^{+}$cations from the metal surface to the film/solution interface where it can combine with sulphide from solution leading to film growth. In order to maintain film growth at the film/solution interface, growth within the pores must be limited in order to avoid blockage and a switch to control of growth by transport through the film. Fig. 3 illustrates this

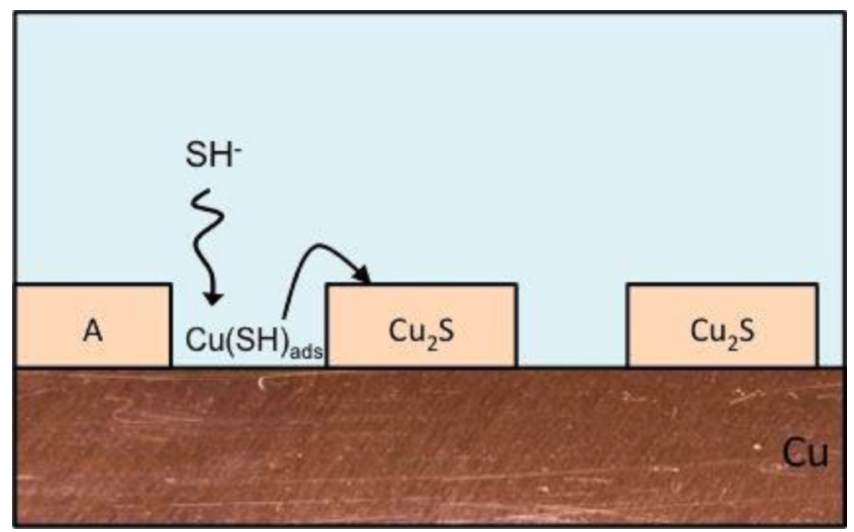

Fig. 3. Schematic illustrating the growth of a compact $\mathrm{Cu}_{2} \mathrm{~S}$ film at the film solution interface by transport of $\mathrm{SH}^{-}$through a network of fine pores in the film. The relative dimensions of the films and pores are not to scale.

mechanism schematically, although the dimensions of the porous network were much tighter than illustrated.

Fig. 4 shows SEM images of the film surface and of a FIB cut crosssection in the film. The film had a small granular structure. Since the $\mathrm{Cu} / \mathrm{film}$ interface was clearly visible, the film could be shown to have an average, and generally uniform, thickness of $\sim 60 \mathrm{~nm}$. This film was difficult to image since it almost instantaneously decomposed in the electron beam. This was apparent in the FIB image in which the cross section was not a sharp cut but almost a bubbled edge. However, close inspection shows the individual $\mathrm{Cu}_{2} \mathrm{~S}$ crystals were $\sim 20 \mathrm{~nm}$ in lateral dimension and the porous network was
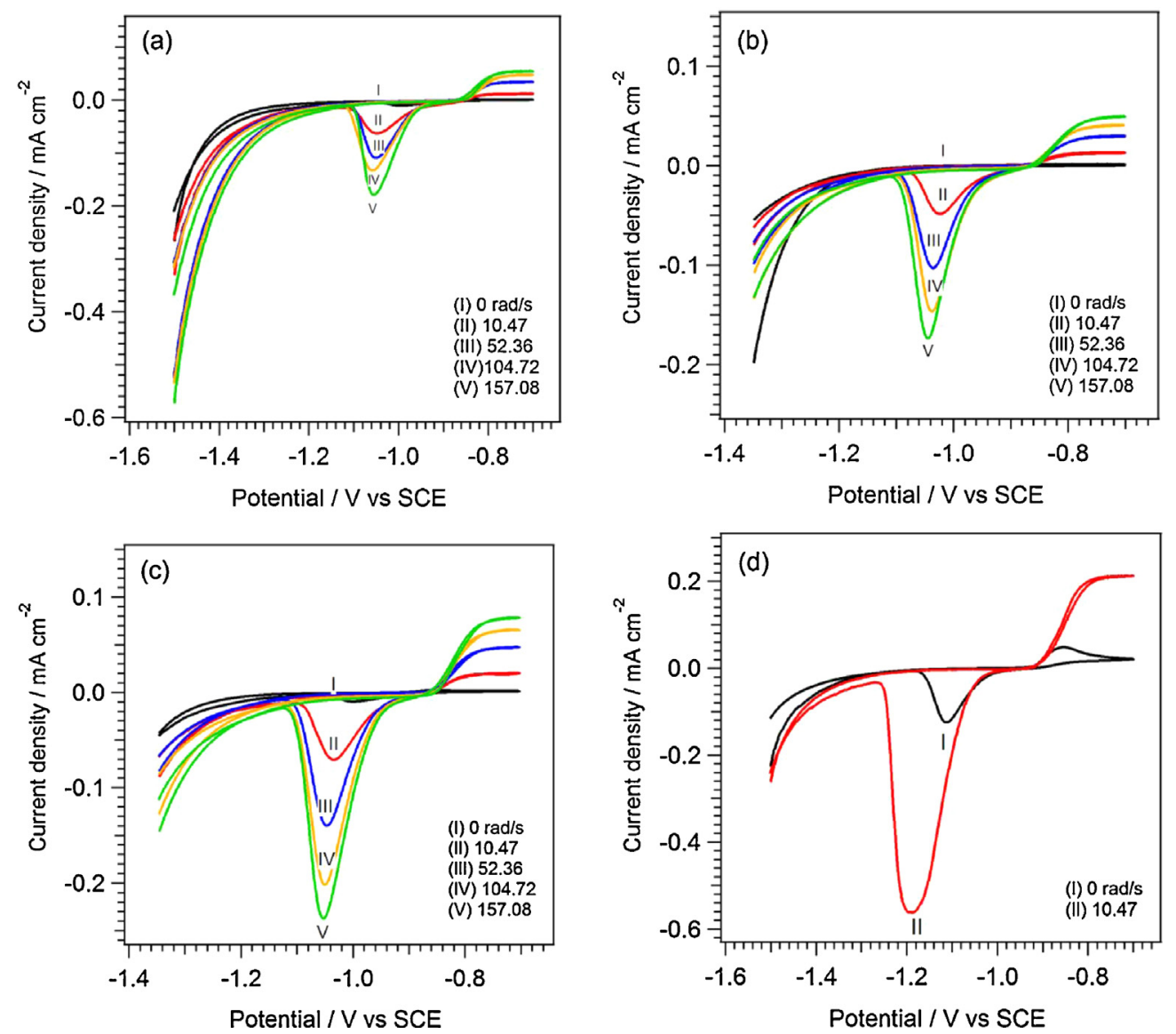

Fig. 2. CVs showing the formation of a Type $\mathrm{ICu}_{2} \mathrm{~S}$ film at various electrode rotation rates: (a) $0.1 \mathrm{M}$ chloride $+5.0 \times 10^{-5} \mathrm{M}$ sulphide; (b) $5.0 \mathrm{M}$ chloride $+5.0 \times 10^{-5} \mathrm{M}$ sulphide; (c) $1.0 \mathrm{M}$ chloride $+5.0 \times 10^{-5} \mathrm{M}$ sulphide; (d) $0.1 \mathrm{M}$ chloride $+5.0 \times 10^{-4} \mathrm{M}$ sulphide. 

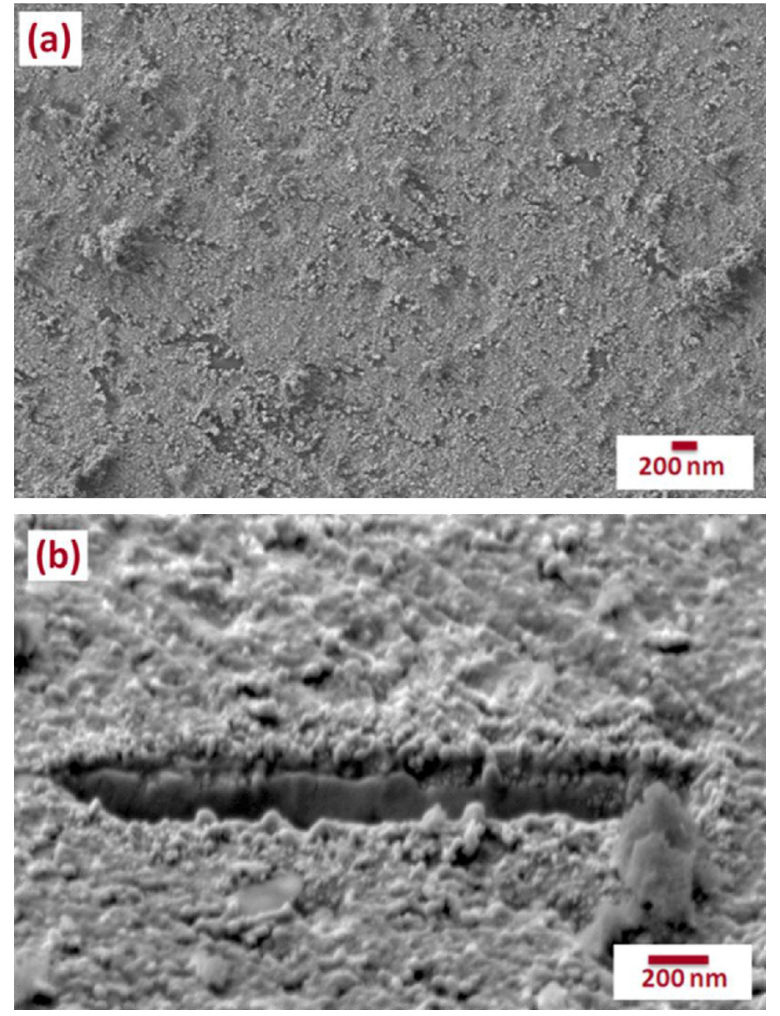

Fig. 4. (a) SEM micrograph of a $\mathrm{Cu}_{2} \mathrm{~S}$ film; and (b) FIB cross section of the porous $\mathrm{Cu}_{2} \mathrm{~S}$ film. The film was grown in a $0.1 \mathrm{M}$ chloride $+5.0 \times 10^{-5} \mathrm{M}$ sulphide solution at a rotation rate of $157 \mathrm{rad} / \mathrm{s}$ during a $\mathrm{CV}$ that was terminated at the anodic potential limit.

very fine and uniformly distributed across the electrode surface. There was no indication of localized behavior.

\subsection{Type II-Porous dual layer $\mathrm{Cu}_{2} \mathrm{~S}$ film}

Type II films were formed at the lowest $\left[\mathrm{Cl}^{-}\right]$(Table 1 ) in the $\left[\mathrm{SH}^{-}\right]$range of $5.0 \times 10^{-4} \mathrm{M}$ to $2.0 \times 10^{-3} \mathrm{M}$ provided the electrode rotation rate was $\geq 10.5 \mathrm{rad} / \mathrm{s}$. These $\left[\mathrm{SH}^{-}\right]$were higher than those leading to the formation of the single layer porous Type I film as described in section 3.1. Similar Type II films were observed in solutions with mid to high $\left[\mathrm{Cl}^{-}\right](0.5 \mathrm{M}$ to $5.0 \mathrm{M})$, and $\left[\mathrm{SH}^{-}\right]$ between $5.0 \times 10^{-4} \mathrm{M}$ and $2.0 \times 10^{-3} \mathrm{M}$. At a $\left[\mathrm{Cl}^{-}\right]$of $0.5 \mathrm{M}$ and $1.0 \mathrm{M}$ at the lowest $\left[\mathrm{SH}^{-}\right]$this type of film was produced only when the rotation rate was $\geq 10.5 \mathrm{rad} / \mathrm{s}$. However for a $\left[\mathrm{Cl}^{-}\right]$of $3.0 \mathrm{M}$ and $5.0 \mathrm{M}$ at similar $\left[\mathrm{SH}^{-}\right]$, porous dual layer films formed at all rotation rates, and at the highest $\left[\mathrm{SH}^{-}\right]$for $\left[\mathrm{Cl}^{-}\right]$of $0.5 \mathrm{M}$ to $5.0 \mathrm{M}$, Type II films were observed only at rotation rates $\leq 52.4 \mathrm{rad} / \mathrm{s}$.

The voltammetric behaviour observed when a Type II film was formed is shown in Fig. 5. In the CV, a small anodic pre-plateau was commonly observed, which sometimes appeared as a peak. This was indicated by an arrow and numbered 1 in Fig. 6. Subsequently, the current rose to the main current plateau region (2 in Fig. 6). As for Type I films the plateau, or limiting current, at the most anodic potentials was dependent on rotation rate confirming there was a major contribution of mass transport to the film growth process. As for Type I films the anodic current retraced its original path on the reverse scan indicating film growth was reversible and that passivation did not occur.

Two reduction peaks were observed when Type II films were grown as opposed to one for Type I films. Gradually increasing the anodic potential limit in the CV, Fig. 7, shows that the first reduction peak was associated with the first anodic oxidation process (1). The current associated with this first anodic process was small compared to the final plateau current (2). Also, its size was not particularly influenced by electrode rotation rate. Similarly, the current and charge associated with the peak for its reduction changed only marginally with electrode rotation rate. The size of the second reduction peak ( 2 ' in the cathodic scan, Fig. 7$)$ was governed by the plateau current achieved ( 2 in the anodic scan, Fig. 7). The anodic plateau current increased with electrode rotation rate which lead to an increase in size of cathodic reduction peak 2, indicating this film grew in a similar manner to the Type I film. Integration of the anodic and cathodic sections of the CVs showed all the oxidation charge again went to film growth with no detectable loss by dissolution. The presence of two reduction peaks indicated that two distinct films were formed: (i) one which grew initially but to a limited thickness (anodic reaction (1)); and (ii) a second film (anodic reaction (2)), which grew at higher potentials and whose thickness increased with increased anodic current, and possessed similar characteristics to a Type I film.

It is proposed that, at these higher [ $\left.\mathrm{SH}^{-}\right]$, coherent film growth could occur at the $\mathrm{Cu} / \mathrm{film}$ interface providing a reasonable $\mathrm{SH}^{-}$ flux was maintained by electrode rotation. This would be expected to lead to a thin passive film with growth controlled by transport processes within the film. However, growth at this interface was limited by the build up of interfacial stress leading to film fracture, the Pilling-Bedworth ratio for $\mathrm{Cu}_{2} \mathrm{~S}$ on $\mathrm{Cu}$ being 2 . This attempt to passivate followed by breakdown would account for the shoulder ( 1 in Fig. 6) in the anodic section of the voltammetric profile. Following breakdown of this potential barrier layer rapid transport of $\mathrm{Cu}^{+}$to the film solution interface became possible leading to the growth of a Type I porous film ( 2 in Fig. 6). Film growth at the film/solution interface did not cause a build up of interfacial stress and growth of the outer $\mathrm{Cu}_{2} \mathrm{~S}$ layer (peak 2) continued unimpeded at a rate at least partially controlled by $\mathrm{SH}^{-}$diffusion to the film/solution interface.

It is clear from Fig. 5 that $\mathrm{Cl}^{-}$had an important effect on film growth behaviour and the structure of the $\mathrm{Cu}_{2} \mathrm{~S}$ film. As $\left[\mathrm{Cl}^{-}\right]$was increased from $0.1 \mathrm{M}$ (Fig. 5(a)) to $5.0 \mathrm{M}$ (Fig. 5(d)) the anodic plateau current decreased and the two reduction peaks became much more distinct, suggesting chloride played a role in the film growth/fracturing at the $\mathrm{Cu} /$ film interface. A possibility is that $\mathrm{Cl}^{-}$ enforced a more open porous structure when present at very high concentrations.

Fig. 8 shows a schematic of the dual copper (I) sulphide film (Type II) where (A) was the initial compact and coherent film (which started to grow in the pre-plateau region 1, Fig. 6) and (B) was the thicker, more porous, $\mathrm{Cu}_{2} \mathrm{~S}$ film grown in plateau region 2, Fig. 6. An SEM image of this film, Fig. 9(a), shows that the $\mathrm{Cu}_{2} \mathrm{~S}$ crystals were much larger $(\sim 100 \mathrm{~nm})$ than for Type I films $(\sim 20 \mathrm{~nm})$. The FIB cross section clearly shows the $\mathrm{Cu} /$ film interface, Fig. 9(b), and shows the film grew to a thickness, although uneven, in the range of 160 to $180 \mathrm{~nm}$, compared to only $\sim 60 \mathrm{~nm}$ for Type I films. This increased film thickness is consistent with the higher $\left[\mathrm{SH}^{-}\right]$ present when Type II films were formed. Two distinct layers cannot be distinguished, which is not surprising since Fig. 5 shows the amount of charge associated with process 1 was small compared to that associated with process 2 . It is also possible that some decomposition of the film in the ion beam obscured the boundary between the two layers. As for Type I films, the porous network of the film was generally fine (on the scale of the crystals) and uniformly distributed, although a number of larger pores were also present. Inspection of the $\mathrm{Cu} / \mathrm{film}$ interface showed no evidence of pitting. This is consistent with the presence of a uniformly distributed porous outer layer (Type II film) and confirms that anodic dissolution did not occur locally at pit locations including at locations where larger individual pores were present in the film, Fig. 9. 

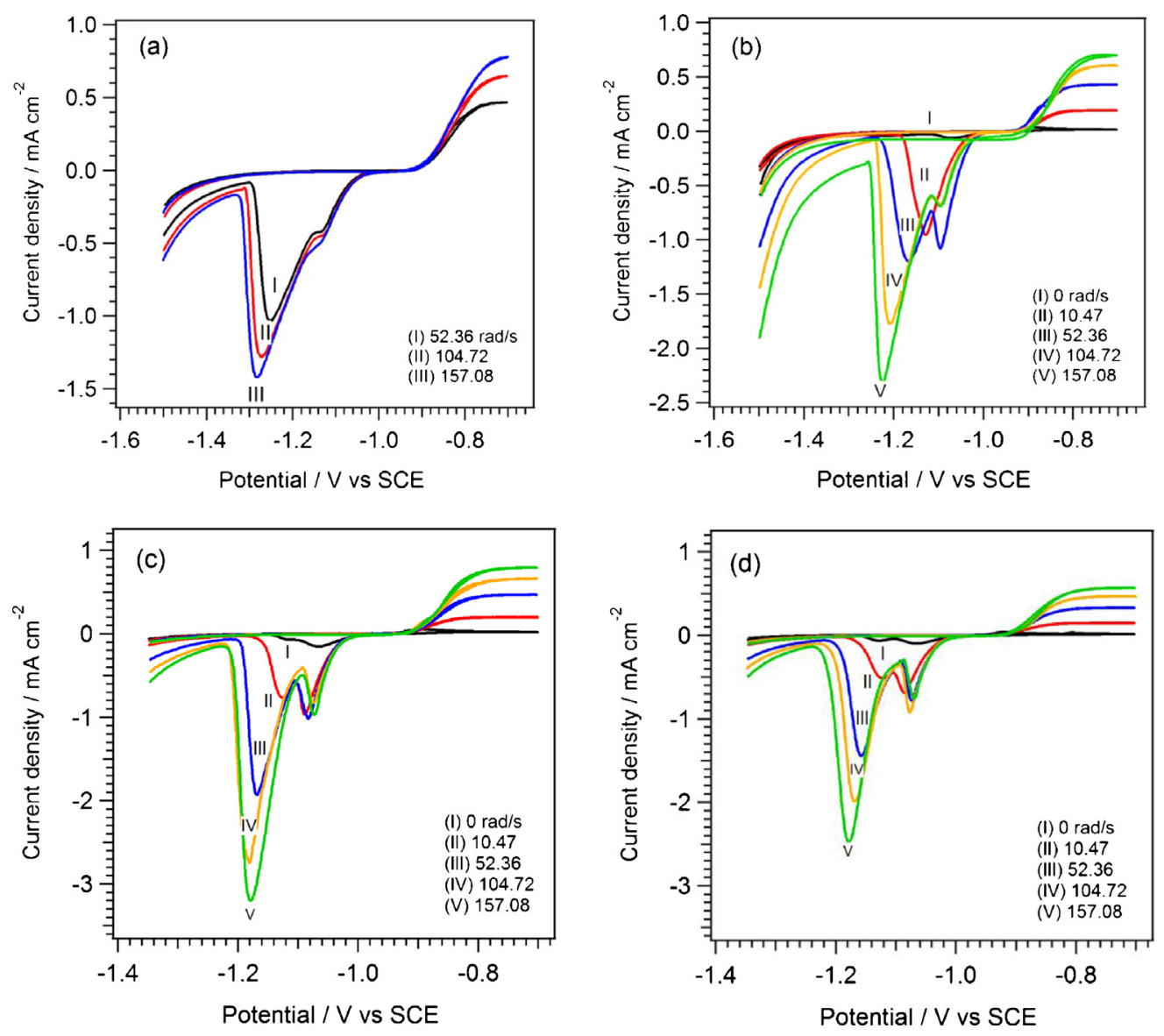

Fig. 5. CVs showing the formation of a Type II $\mathrm{Cu}_{2} \mathrm{~S}$ film at various electrode rotation rates: (a) $0.1 \mathrm{M}$ chloride $+5.0 \times 10^{-4} \mathrm{M}$ sulphide; (b) $0.5 \mathrm{M}$ chloride $+5.0 \times 10^{-4} \mathrm{M}$ sulphide; (c) $3.0 \mathrm{M}$ chloride $+5.0 \times 10^{-4} \mathrm{M}$ sulphide; (d) $5.0 \mathrm{M}$ chloride $+5.0 \times 10^{-4} \mathrm{M}$ sulphide.

\subsection{Type III-Partially-passivating film}

The formation of Type III film was limited to the two highest [SH $\left.{ }^{-}\right]$studied: $1.0 \times 10^{-3} \mathrm{M}$ and $2.0 \times 10^{-3} \mathrm{M}$. For $1.0 \times 10^{-3} \mathrm{M}$ sulphide the formation of a partially passivating film was observed only at high $\left[\mathrm{Cl}^{-}\right](3.0 \mathrm{M}$ and $5.0 \mathrm{M})$ and high electrode rotation rates. At lower $\left[\mathrm{Cl}^{-}\right]$, but the same $\left[\mathrm{SH}^{-}\right]$and electrode rotation rates, the anodic current for film growth at positive potentials became considerably lower than the theoretical diffusion limited current for $\mathrm{SH}^{-}$, suggesting film growth became partially

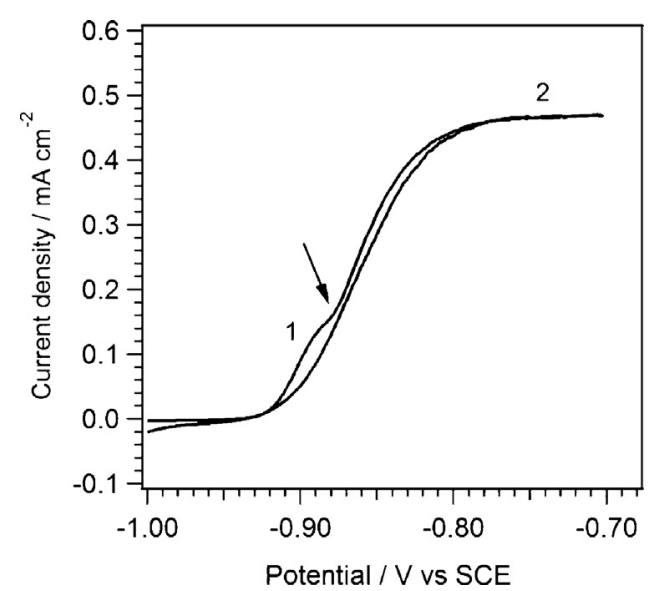

Fig. 6. A section of the anodic scan of a CV recorded in $3.0 \mathrm{M}$ chloride $+5.0 \times 10^{-4} \mathrm{M}$ sulphide solution at a rotation rate of $52.4 \mathrm{rad} / \mathrm{s}$. chemically-controlled. However, passivation did not occur (i.e. the current did not decrease to a lower value). At the highest $\left[\mathrm{SH}^{-}\right]$ $\left(2.0 \times 10^{-3} \mathrm{M}\right)$ partial passivation occurred at high electrode rotation rates $\left(\geq 52.4 \mathrm{rad} / \mathrm{s}\right.$ ) irrespective of the $\left[\mathrm{Cl}^{-}\right]$.

These features can be seen in the voltammetric behaviour, Fig. 10. As expected, the anodic currents were considerably higher than those observed at lower [ $\left.\mathrm{SH}^{-}\right]$, Fig. 10 (a), but separation into two distinct films (as indicated by two distinct reduction peaks) was poor at low $\left[\mathrm{Cl}^{-}\right]$. As the positive anodic limit was approached, instead of rising to a plateau, as observed for Type I and Type II films, the current tended to peak. At high $\left[\mathrm{SH}^{-}\right]$and low $\left[\mathrm{Cl}^{-}\right]$, Fig. 10(b), the current fell immediately to almost zero when the

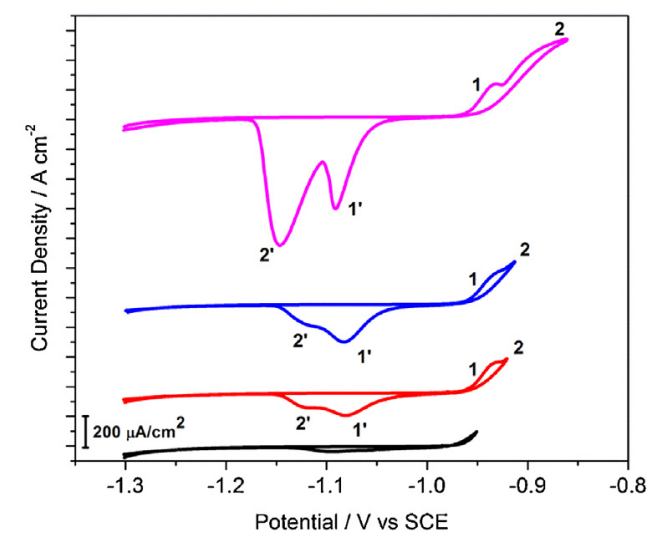

Fig. 7. CVs to various anodic limits obtained in $5.0 \mathrm{M}$ chloride $+2.0 \times 10^{-3} \mathrm{M}$ sulphide solution and $10.5 \mathrm{rad} / \mathrm{s}$. 


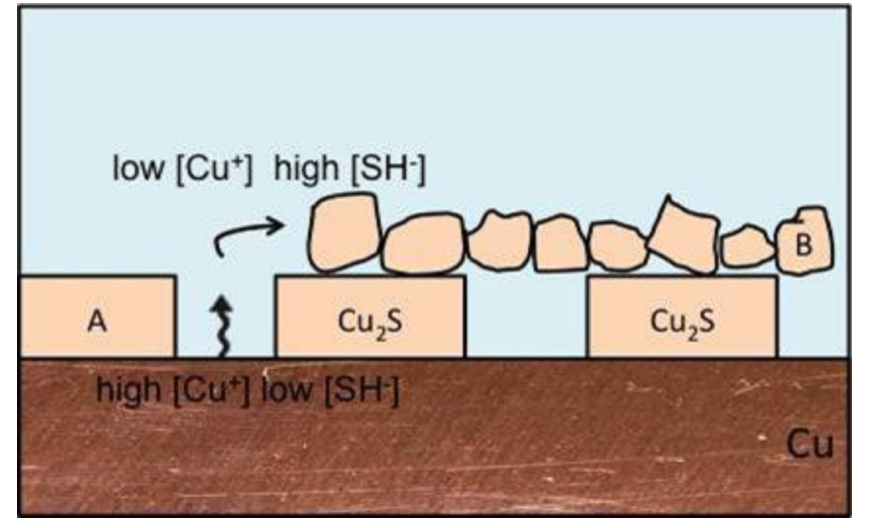

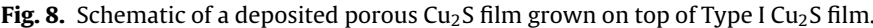
The relative dimensions of the layers $\mathrm{A}$ and $\mathrm{B}$ are not to scale.

potential scan was reversed as opposed to retracing the forward scan as observed for Type I and II films. This fall in current indicated that film growth could only be sustained by the increasing electric field across the film imposed by the increasing potential. Once the potential was reversed this field became insufficient to drive the transport processes within the film required to maintain growth. At high $\left[\mathrm{Cl}^{-}\right]$, when the film was expected to be porous, partial passivation was observed as a drop in current at positive anodic potentials, Fig. 10(d). When this drop was observed, the cathodic scan showed the presence of a third film reduction peak, 3 in Fig. 10(c).
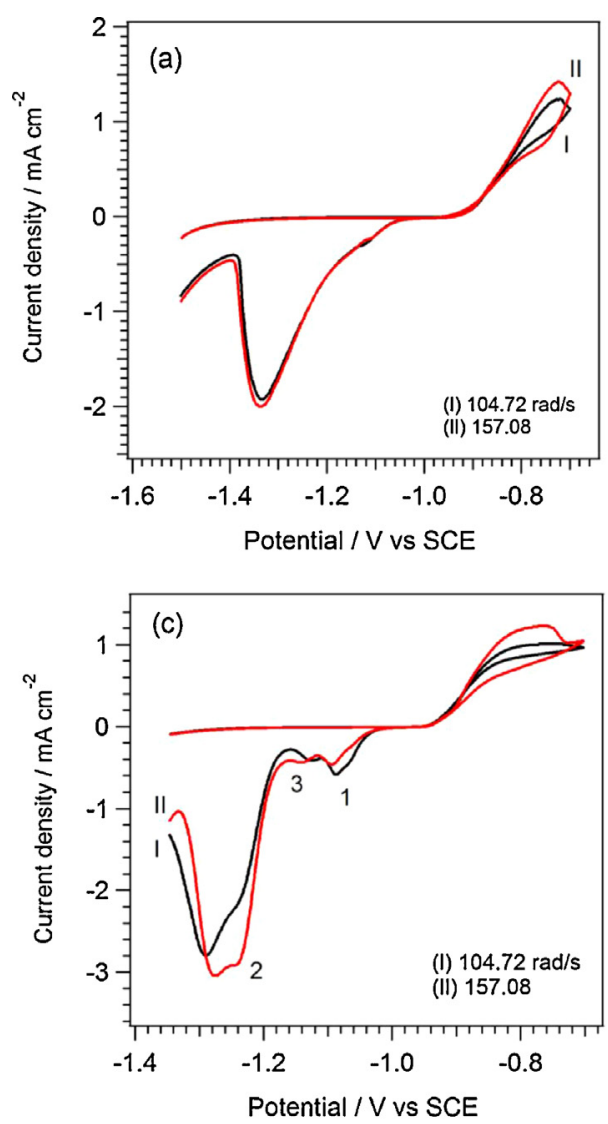
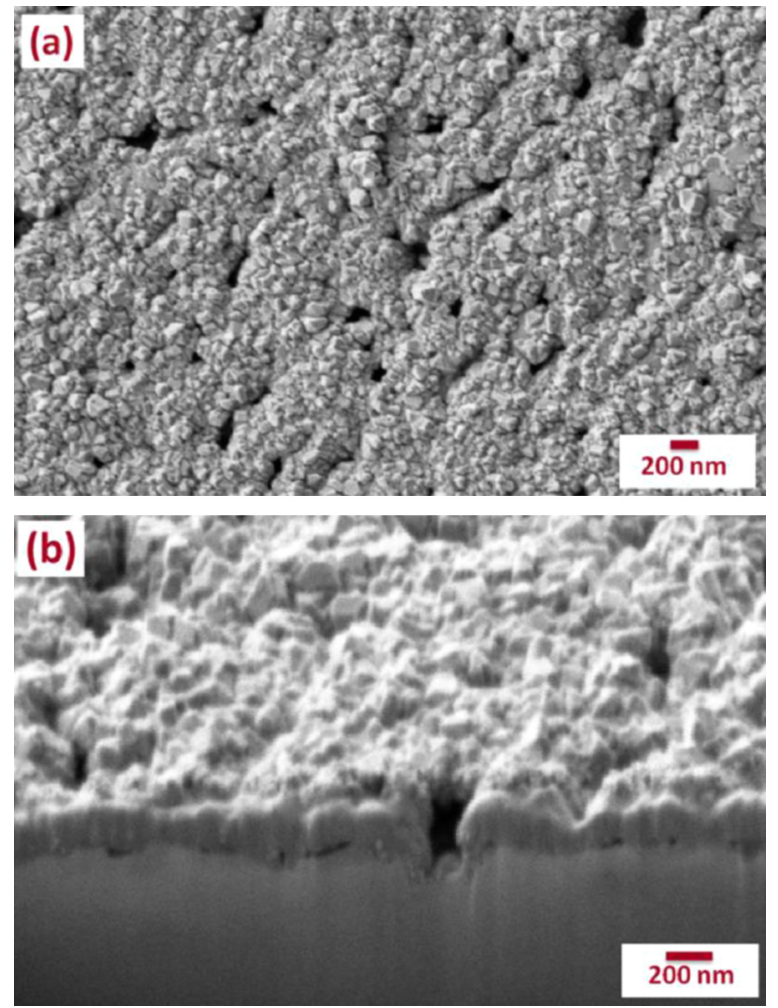

Fig. 9. (a) SEM image of a porous Type II $\mathrm{Cu}_{2} \mathrm{~S}$ film surface; and (b) FIB cross section of the film. The film was grown in a $1.0 \mathrm{M}$ chloride $+1.0 \times 10^{-3} \mathrm{M}$ sulphide solution at an electrode rotation rate of $52.36 \mathrm{rad} / \mathrm{s}$.
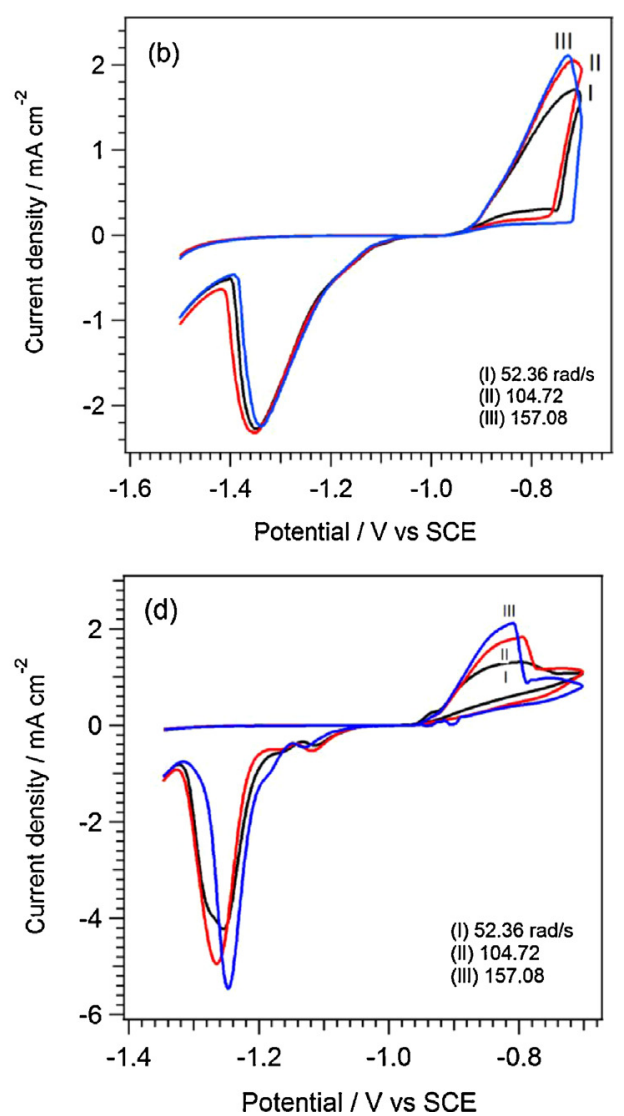

Fig. 10. CVs showing the formation of a Type III CuS film at various rotation rates: (a) $0.1 \mathrm{M}$ chloride $+1.0 \times 10^{-3} \mathrm{M}$ sulphide; (b) $0.1 \mathrm{M}$ chloride $+2.0 \times 10^{-3} \mathrm{M}$ sulphide; (c) $5.0 \mathrm{M}$ chloride $+1.0 \times 10^{-3} \mathrm{M}$ sulphide; (d) $5.0 \mathrm{M}$ chloride $+2.0 \times 10^{-3} \mathrm{M}$ sulphide. 


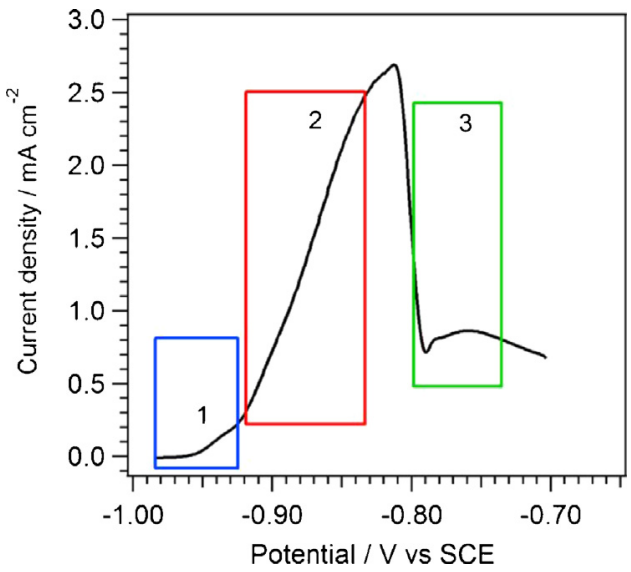

Fig. 11. Section of the anodic scan of a CV recorded in $3.0 \mathrm{M}$ chloride $+2.0 \times 10^{-3} \mathrm{M}$ sulphide solution at $157 \mathrm{rad} / \mathrm{s}$. The numbers indicate three distinct regions of behaviour.

This behaviour can be summarized as follows, Fig. 11. In anodic region 1, the surface attempted to passivate, as observed for Type II films and the reduction of this film occurred at cathodic peak 1 , Fig. 10(c). As discussed above, this film rapidly fractured leading to the large increase in current in region 2. This Type II film was subsequently reduced at cathodic peak 2 , Fig. 10(c). In region 3 , the decrease in anodic current leading to partial passivation generated reduction peak 3 in the reverse scan, Fig. 10(c). The sites for $\mathrm{Cu}$ oxidation leading to the outer layer film (2 in Fig. 11 and 10(c)) were at the base of pores in the initially formed thin base layer.

The SEM and SEM-FIB images, Fig. 12, showed the surface of the $\mathrm{Cu}$ when partial passivation had occurred and a Type III film was present. The film had a uniform thickness of $\sim 230 \mathrm{~nm}$ and was apparently less porous than Type II films, Fig. 9. While some
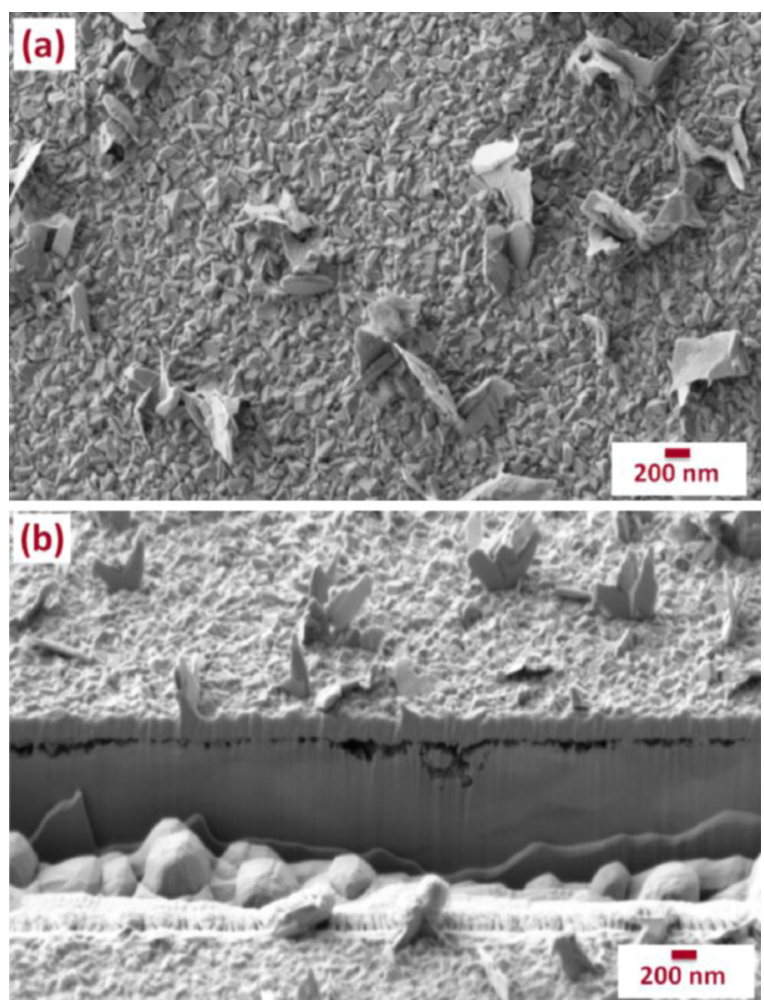

Fig. 12. (a) SEM image of a passive copper sulphide film surface; (b) FIB cross section of a passive copper sulphide film. The film was grown in a $5.0 \mathrm{M}$ chloride $+2.0 \times 10^{-3} \mathrm{M}$ sulphide solution at a rotation of $157.08 \mathrm{rad} / \mathrm{s}$.

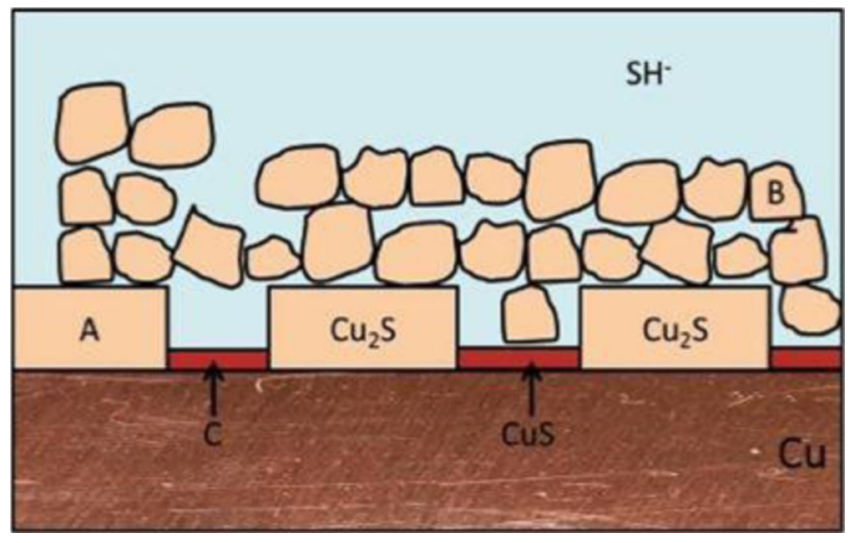

Fig. 13. Schematic showing the format ion of a passive CuS layer (designated C) at the base of pores in a Type II $\mathrm{Cu}_{2} \mathrm{~S}$ film.

localized corrosion of the $\mathrm{Cu}$ interface was apparent in the cross section image, Fig. 12, there was no evidence for widespread development of pits. A schematic of a Type III film is shown in Fig. 13, with passivation indicated to occur by blockage of the pores in the film at the $\mathrm{Cu} /$ film interface. It is possible that passivation was more widespread and involved conversion of the $\mathrm{Cu}_{2} \mathrm{~S}$ to $\mathrm{CuS}$ [13] (or $\mathrm{Cu}_{\mathrm{x}} \mathrm{S}$ with compositions in the range $\mathrm{Cu}_{1.98} \mathrm{~S}$ to $\mathrm{Cu}_{1.75} \mathrm{~S}$ [14-17]) across the film/solution interface. If so, this universally passivating layer would have to have been very thin since the charge associated with its reduction (proportional to the area under reduction peak 3, Fig. 10(c)) was small. However the minimum area that must be passivated was that at the base of pores in the initially grown Type I film.

A key point is that the initially grown $\mathrm{Cu}_{2} \mathrm{~S}$ film (1 in Fig. 11) did not lead to passivation and substantial growth of the outer layer film (2 in Fig. 11) occurred before partial passivation was observed at considerably more positive potentials (3 in Fig. 11).

Fig. 14 attempts to summarize the various conditions under which the three type of films were formed, as a function of $\left[\mathrm{SH}^{-}\right]$ and $\left[\mathrm{Cl}^{-}\right]$and electrode rotation rate. The latter parameter was included since, as indicated by the dependence of anodic film growth on electrode rotation rate, the flux of $\mathrm{SH}^{-}$to the electrode surface was important in determining the kind of film formed. From this figure it is clear that the key features dictating the nature of the film were the bulk $\left[\mathrm{SH}^{-}\right]$and the electrode rotation rate.

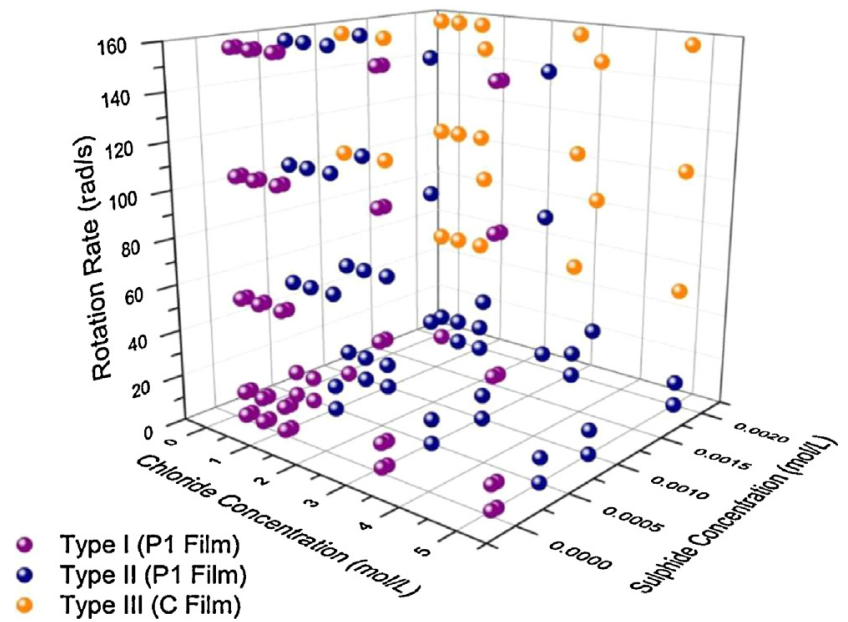

Fig. 14. 3D Plot displaying various film types at different $\left[\mathrm{SH}^{-}\right],\left[\mathrm{Cl}^{-}\right]$and electrode rotation rates. The $\mathrm{P} 1 \mathrm{film}$ is a porous film and the $\mathrm{C}$ film is a compact and coherent film. 
At low $\left[\mathrm{SH}^{-}\right]\left(\leq 1.0 \times 10^{-4} \mathrm{M}\right)$ porous Type I films were formed irrespective of the $\left[\mathrm{Cl}^{-}\right]$or electrode rotation rate. Additionally, as the $\mathrm{SH}^{-}$flux to the electrode surface decreased (i.e., the rotation rate approached 0 ) porous Type I and II films were always found irrespective of the $\left[\mathrm{SH}^{-}\right]$and $\left[\mathrm{Cl}^{-}\right]$. Partially passive Type III films were formed only at high $\left[\mathrm{SH}^{-}\right]$although the threshold $\left[\mathrm{SH}^{-}\right]$for their formation was decreased providing the flux of $\left[\mathrm{SH}^{-}\right]$was increased to maintain a high interfacial $\left[\mathrm{SH}^{-}\right]$.

It can be concluded that passive films which could lead to the conditions which could support pitting, were only formed for $\left[\mathrm{SH}^{-}\right]$ $\geq 5.0 \times 10^{-4} \mathrm{M}$ and then only at high $\mathrm{SH}^{-}$fluxes (proportional to the rotation rate) when depletion of $\mathrm{SH}^{-}$at the $\mathrm{Cu}$ surface would be minimized, and the generally formed porous Types I and II films avoided. No clear influence of $\left[\mathrm{Cl}^{-}\right]$was apparent in this figure indicating that while it may influence the porosity of the films formed it was not the primary factor controlling the type of film formed.

If it is assumed that passivity is a prerequisite for pitting these results indicate that pitting should not occur for $\left[\mathrm{SH}^{-}\right]<5 \times 10^{-4} \mathrm{M}$ and should not occur at all, irrespective of $\left[\mathrm{SH}^{-}\right]$and $\left[\mathrm{Cl}^{-}\right]$, as stagnant conditions (rotation rate $<20 \mathrm{rad} / \mathrm{s}$ ) are approached.

These electrochemical results can be compared to those obtained in long-term (up to $4000 \mathrm{~h}$ ) corrosion experiments. When the $\left[\mathrm{SH}^{-}\right]$was high (i.e., $\geq 5 \times 10^{-4} \mathrm{M}$ ) and the $\left[\mathrm{Cl}^{-}\right]$was low (i.e., $\leq 0.5 \mathrm{M}$ ) the corrosion product formed was a single compact $\mathrm{Cu}_{2} \mathrm{~S}$ film (chalcocite, as demonstrated by XPS and XRD). Growth of this crystalline film obeyed a parabolic law $[9,12,18]$, indicating that the film was protective under these conditions, the overall corrosion process being dominated by $\mathrm{Cu}^{+}$diffusion through the $\mathrm{Cu}_{2} \mathrm{~S}$ film with a contribution from $\mathrm{SH}^{-}$diffusion from the bulk solution to the film/solution interface.

When the $\left[\mathrm{SH}^{-}\right]$was low (i.e., $\leq 5 \times 10^{-4} \mathrm{M}$ ), the $\mathrm{Cu}_{2} \mathrm{~S}$ film formed was porous and its growth was linear with exposure time $[12,18,19]$, indicating that the film formed under these conditions was not protective, the corrosion process being mainly controlled by $\mathrm{SH}^{-}$diffusion in solution and/or pores. A similarly porous film was observed at higher $\left[\mathrm{SH}^{-}\right]\left(10^{-3} \mathrm{M}\right)$ if $\left[\mathrm{Cl}^{-}\right]$was increased to $1.0 \mathrm{M}$. These observations are consistent with the electrochemical observation that a dominant influence of $\left[\mathrm{Cl}^{-}\right]$was to enhance the porosity of the film even as the $\left[\mathrm{SH}^{-}\right]$increased. When the $\left[\mathrm{Cl}^{-}\right]$ was very high (i.e. $5.0 \mathrm{M}$,), the $\mathrm{Cu}_{2} \mathrm{~S}$ film grew two-dimensionally with pores between plates. The corrosion process appeared to be assisted by $\mathrm{CuCl}_{2}{ }^{-}$diffusion in the pores and $\mathrm{SH}^{-}$diffusion in the solution. Although the behaviour under these conditions has not been completely characterized, it was clear the film offered no corrosion protection. In all the tested solutions and conditions, no pitting corrosion was observed.

As observed in the voltammetric experiments the formation of a compact film, requires a high $\left[\mathrm{SH}^{-}\right]$. Since the $\left[\mathrm{SH}^{-}\right]$ and $\left[\mathrm{Cl}^{-}\right]$in a Swedish repository are expected to be in the ranges $10^{-6 \sim 7} \mathrm{M}$ to $10^{-4} \mathrm{M}$ and $0.1 \mathrm{M}$ to $1.4 \mathrm{M}$ [20], respectively, passive conditions will not be achieved. Given the slow diffusive transport conditions expected in the compacted clay environment surrounding an emplaced container, the $\left[\mathrm{SH}^{-}\right]$at the container surface will be at the low end of this range and probably considerably lower [21]. Again, these results are consistent with the electrochemical results which show porous films are obtained irrespective of $\left[\mathrm{SH}^{-}\right]$and $\left[\mathrm{Cl}^{-}\right]$as stagnant conditions (very low electrode rotation rates) are approached. Thus, under repository conditions, the $\mathrm{Cu}_{2} \mathrm{~S}$ films formed will almost certainly be porous and container corrosion controlled by transport processes. Since the prerequisite for pitting, the presence of a compact passive layer cannot be satisfied, it is most unlikely sulphide-induced pitting corrosion will occur under repository conditions. Furthermore, the $\left[\mathrm{Cl}^{-}\right]$required for corrosion to be assisted by $\mathrm{CuCl}_{2}{ }^{-}$transport appears to be well beyond that anticipated under repository conditions.

\section{Conclusions}

Under polarization conditions, the morphology of the sulphide film formed on $\mathrm{Cu}$ in aqueous sulphide solutions has been shown to be dependent on the $\left[\mathrm{SH}^{-}\right]$, the flux of sulphide to the electrode surface, and the $\left[\mathrm{Cl}^{-}\right]$of the solution.

Three distinct type of films have been observed: Type I film-a single layer porous $\mathrm{Cu}_{2} \mathrm{~S}$ film, identified by one reduction peak in a CV; Type II film-a porous dual layer $\mathrm{Cu}_{2} \mathrm{~S}$ film, identified by two reduction peaks in a CV; and Type III film-a compact, partiallypassivating film, identified by an additional third peak in a CV.

When the film growth is dominated by sulphide diffusion in solution, a porous film (Type I or II) forms, whereas if film growth is controlled by an interfacial reaction, a compact Type III film forms. These observations are consistent with the results of long-term corrosion experiments under natural corrosion conditions.

Partially passive Type III films are formed only at high $\left[\mathrm{SH}^{-}\right]$ and high electrode rotation rates, when the flux of sulphide at the film/electrolyte interface is sufficiently large that film growth is controlled by interfacial reactions.

It can be concluded that passive films, which could lead to the conditions able to support pitting, are only formed for $\left[\mathrm{SH}^{-}\right] \geq$ $5.0 \times 10^{-4} \mathrm{M}$ and then only at high $\mathrm{SH}^{-}$fluxes (electrode rotation rates). These conditions are not possible within a waste repository.

\section{Acknowledgement}

This project is funded by the Swedish Nuclear Fuel and Waste Management Company (SKB), Stockholm, Sweden. The authors are grateful to Christina Lilja (SKB) and Fraser King (Integrity Corrosion Consulting, Nanaimo, BC, Canada) for many helpful discussions and suggestions.

\section{References}

[1] F. King, C. Lilja, K. Pedersen, P. Pitkänen, M. Vähänen, An update of the state-ofthe-art report on the corrosion of copper under expected conditions in a deep geologic repository, SKB Technical Report, TR-10-67, 2010.

[2] F. King, Corrosion of copper in alkaline chloride environments, SKB Swedish Nuclear Fuel and Waste Management Co., Technical Report, TR-02-25, 2002.

[3] SKB Swedish Nuclear Fuel and Waste Management Co., Corrosion calculations report for the safety assessment SR-Site, SKB Technical Report, TR-10-66, 2010

[4] SKB Swedish Nuclear Fuel and Waste Management Co., Long-term safety for the final repository for spent nuclear fuel at Forsmark, Main report of the SR-Site project, SKB Technical Report, TR-11-01, 2011.

[5] J. McMurry, D.A. Dixon, J.D. Garroni, B.M. Ikeda, S. Stroes-Gascoyne, P. Baumgartner, T.W. Melnyk, Evolution of a Canadian deep geologic repository: Base scenario, Ontario Power Generation Report No. 06819-REP-01200-10092-R00, 2003.

[6] J. McMurry, Reference water compositions for a deep geologic repository in the Canadian shield, Ontario Power Generation Report, No. 06819-REP-0120010135, 2004

[7] J.M. Smith, J.C. Wren, M. Odziemkowski, D.W. Shoesmith, The electrochemical response of preoxidized copper in aqueous sulfide solutions, J. Electrochem. Soc. 154 (8) (2007) C431-C438.

[8] R. Sandström, H.C.M. Andersson, The effect of phosphorus on creep in copper J. Nucl. Mater. 372 (1) (2008) 66-75.

[9] J. Chen, Z. Qin, D.W. Shoesmith, Kinetics of corrosion film growth on copper in neutral chloride solutions containing small concentrations of sulfide, J. Electrochem. Soc. 157 (10) (2010) C338-C345

[10] M. Kruft, B. Wohlmann, C. Stuhlmann, K. Wandelt, Chloride adsorption on $\mathrm{Cu}(111)$ electrodes in dilute $\mathrm{HCl}$ solutions, Surf. Sci. 377 (1-3) (1997) 601-604.

[11] J. Chen, Z. Qin, D.W. Shoesmith, Long-term corrosion of copper in a dilute anaerobic sulfide solution, Electrochim. Acta 56 (23) (2011) 7854-7861.

[12] J. Chen, Z. Qin, D.W. Shoesmith, Rate controlling reactions for copper corrosion in anaerobic aqueous sulphide solutions, Corros. Eng., Sci. Technol. 46(2)(2011) $138-141$

[13] E.M. Khairy, N.A. Darwish, Studies on copper-semiconducting layer electrolyte systems-I. Electrode potentials of copper and electrodeposited copper sulphide in $\mathrm{S}^{2-}$ and $\mathrm{Cu}^{+}$media, Corros. Sci. 13 (1973) 141-147.

[14] I. Puigdomenech, Thermodynamic data for copper. Implications for the corrosion of copper under repository conditions, SKB Technical Report, TR-00-13, 2000.

[15] B.W. Mountain, T.M. Seward, The hydrosulphide/sulphide complexes of copper (I): Experimental determination of stoichiometry and stability at $22 \mathrm{C}$ and 
reassessment of high temperature data, Geochim. Cosmochim. Acta 63 (1999) $11-29$.

[16] J. Smith, Z. Qin, F. King, L. Werme, D.W. Shoesmith, Sulfide film formation on copper under electrochemical and natural corrosion conditions, Corrosion 63 (2) (2007) 135-144

[17] J. Smith, PhD thesis, The University of Western Ontario, London, 2007.

[18] J. Chen, Z.Qin, D. W. Shoesmith, Copper corrosion in aqueous sulphide solutions under nuclear waste repository conditions, Scientific Basis for Nuclear Waste Management XXXV (Buenos Aires, Argentina, Oct. 2-7, 2011), MRS Proceedings 1475, imrc11-1475-nw35-o16.
[19] J. Chen, Z. Qin, D.W. Shoesmith, Copper corrosion in aqueous sulphide solutions under Swedish nuclear waste repository conditions, SKB Progress Report, SKB 2011-05, 2011.

[20] SKB Swedish Nuclear Fuel \& Waste Management Co., Long-term safety for KBS3 repositories at Forsmark and Laxemar-a first evaluation, Main Report of the SR-Can Project, SKB Technical Report, TR-06-09, 2006.

[21] F. King, M. Kolar, M. Vähänen, C. Lilja, Modelling long term corrosion behaviour of copper canisters in KBS-3 repository, Corros. Eng. Sci. Tech. 46 (2) (2011) $217-222$. 